\title{
VARIETY IN THE RESPONSE OF ESCHERICHIA COLI TO ERYTHROMYCIN
}

\author{
D. Greenwood and F. O'Grady \\ Department of Bacteriology, St Bartholomew's Hospital, London E.C.I
}

ERYTHROMYCIN is not usually looked upon as being a useful antibiotic in infections caused by Gram-negative bacilli, which are commonly found, by in-vitro tests, to be relatively resistant to its action. Notwithstanding this, some trials have been made of its clinical efficacy in infections with Gram-negative organisms, and it has several times been shown that clinical advantage can be taken of the increased activity of erythromycin in alkaline solution for the treatment of urinary-tract infection (Zinner et al., 1971). In view of this, we undertook a reappraisal of the activity of erythromycin against enterobacteria, particularly in conditions resembling those likely to occur in the urinary tract.

In the course of these studies we encountered unexpected variety in the effect of the drug on different strains of Escherichia coli, which we now report.

\section{MATERIALS AND METHODS}

Strains of $E$. coli originally derived from urinary-tract infections were used throughout. The minimum inhibitory concentrations (MIC) of erythromycin (Ilotycin gluceptate, Eli Lilly \& Co.) were determined by a standard doubling-dilution technique in nutrient broth at $p \mathrm{H} \mathrm{7.5.}$

Because the high concentration of bacteria found in infected urine may play an important part in determining the response to antibacterial therapy (O'Grady and Pennington, 1967), titrations against one strain of $E$. coli $(F r)$ were repeated with inocula ranging from $10^{2}$ to $10^{8}$ per $\mathrm{ml}$. The effect of the drug was also examined in a system that simulates in some important respects conditions in the urinary bladder. In this system, $30-\mathrm{ml} \mathrm{samples} \mathrm{of} \mathrm{fully}$ grown or near-fully grown broth cultures, resembling those found in infected bladder urine, were constantly diluted at $1 \mathrm{ml}$ per min. with fresh broth (simulating ureteric-urine flow) while being held in the light path of a "Spekker" photometer (O'Grady and Pennington, 1966). Frequent readings were taken, and the results were expressed as the reciprocal of the opacity produced by the culture in excess of the value for uninoculated nutrient broth. In this method the reciprocal of the opacity of a completely inactivated organism will plot against time as a predictable straight line (O'Grady and Pennington, 1967).

\section{RESULTS}

The results of the tube titrations of the 16 strains of E. coli and a comparison of the numbers of organisms originally inoculated and recovered after overnight incubation in nutrient broth at $p \mathrm{H} 7.5$ are shown in table I. A few strains were inhibited by $16 \mu \mathrm{g}$ per $\mathrm{ml}$, but most required 31-62 $\mu \mathrm{g}$ per $\mathrm{ml}$. Two types of response were seen. On five strains (table I; $\mathrm{Mi}, \mathrm{Mo}, \mathrm{No}, \mathrm{Ph}$ and $\mathrm{Wh}$ ) the effect of erythromycin was bactericidal in that no survivors were recovered after

Received 16 Nov. 1971; accepted 21 Jan. 1972.

J. MED. MICROBIOL.-VOL. 5 (1972) 
overnight incubation from tubes showing inhibition of growth. On the remaining 11 strains, the effect was bacteristatic in that the inoculum could be wholly

TABLE I

Bacteristatic and bactericidal effect of erythromycin on 16 strains of Escherichia coli

\begin{tabular}{|c|c|c|c|c|c|c|c|c|c|c|c|}
\hline \multirow{3}{*}{ Strain } & \multirow{3}{*}{ 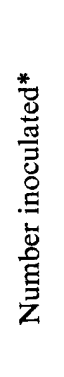 } & \multicolumn{10}{|c|}{$\begin{array}{l}\text { Amount of growth, and numbers of the stated strain of } E \text {. coli recovered*, } \\
\text { after incubation overnight in tubes containing the following concentrations } \\
\text { of erythromycin }(\mu \mathrm{g} \text { per ml }) \dagger:\end{array}$} \\
\hline & & \multicolumn{2}{|c|}{250} & \multicolumn{2}{|c|}{125} & \multicolumn{2}{|c|}{62.5} & \multicolumn{2}{|c|}{$31 \cdot 2$} & \multicolumn{2}{|c|}{16} \\
\hline & & $\begin{array}{l}\text { 总 } \\
\text { 总 } \\
\text { 至 } \\
\text { Z }\end{array}$ & 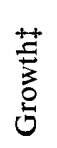 & 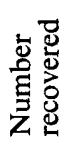 & 莘 & 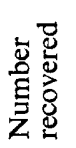 & $\begin{array}{l}\text { 茞 } \\
\text { 莕 }\end{array}$ & 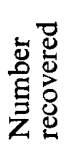 & 葡 & 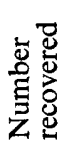 & 莣 \\
\hline$M i$ & & 0 & - & 0 & - & 100 & + & .. & ++ & 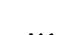 & $+t$ \\
\hline$M o$ & $\begin{array}{l}\text { ou } \\
50\end{array}$ & 0 & - & 0 & - & 0 & - & $\ddot{0}$ & -1 & $\ddot{2}$ & - \\
\hline No & 100 & 0 & - & 0 & - & 0 & - & 0 & - & $\ldots$ & + \\
\hline$P h$ & 80 & 0 & - & 0 & - & 0 & - & $\ldots$ & + & $\ldots$ & ++ \\
\hline$W h$ & $\begin{array}{l}50 \\
50\end{array}$ & 0 & - & 0 & - & & + & 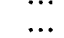 & + & $\ldots$ & $+t$ \\
\hline$B a$ & 50 & 100 & - & 100 & - & 100 & - & 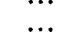 & + & $\ldots$ & $+t$ \\
\hline$B u$ & 100 & 10 & - & 20 & - & 40 & - & & + & $\ldots$ & ++ \\
\hline $\mathrm{Co}$ & 50 & 20 & - & 30 & - & 10 & - & 100 & - & $\ldots$ & ++ \\
\hline $\mathrm{Cr}$ & 80 & 40 & - & 20 & - & 20 & - & $\ldots$ & ++ & $\ldots$ & ++ \\
\hline$F r$ & 50 & 50 & - & 50 & - & 50 & - & $\ldots$ & + & $\ldots$ & ++ \\
\hline $\mathrm{He}$ & 50 & 20 & - & 20 & - & 40 & - & $\ldots$ & + & $\ldots$ & $+t$ \\
\hline Jo & 50 & 50 & - & 40 & - & 100 & + & $\ldots$ & + & $\ldots$ & ++ \\
\hline$M a$ & 80 & 4 & - & 10 & - & 10 & - & $\ldots$ & + & $\ldots$ & ++ \\
\hline$M c$ & 80 & $i$ & - & 20 & - & 50 & - & 1 & - & $\ldots$ & + \\
\hline Ol & 80 & 2 & - & 30 & - & 40 & - & & + & $\ldots$ & $+t$ \\
\hline$T i$ & 30 & 10 & 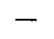 & 30 & & 30 & & 100 & & $\ldots$ & + \\
\hline
\end{tabular}

* In 0.001-ml samples.

$\uparrow$ All strains gave moderate or perfuse growth in $8 \mu \mathrm{g}$ per ml.

$+++=$ Moderate growth; $+=$ slight growth; $-=$ no growth. $\ldots=$ Not done.

TABLE II

Effect of inoculum size on the inhibitory effect of erythromycin on Escherichia coli strain Fr

\begin{tabular}{|c|c|c|c|c|c|c|c|}
\hline \multirow{2}{*}{$\begin{array}{l}\text { Concentration } \\
\text { of } \\
\text { erythromycin } \\
(\mu \mathrm{g} \text { per } \mathrm{ml})\end{array}$} & \multicolumn{7}{|c|}{$\begin{array}{l}\text { Growth (and number of survivors in } 0.001-\mathrm{ml} \text { samples) after overnight incubation of tubes } \\
\text { containing the stated concentrations of erythromycin and inoculated with the following } \\
\text { concentrations of organisms per ml: }\end{array}$} \\
\hline & $10^{8}$ & $10^{7}$ & $10^{6}$ & $10^{5}$ & $10^{4}$ & $10^{3}$ & $10^{2}$ \\
\hline $\begin{array}{r}200 \\
100 \\
50 \\
25 \\
0\end{array}$ & $\begin{array}{r}+(\ldots) \\
++(\ldots) \\
++(\ldots) \\
++(\ldots) \\
+++(\ldots)\end{array}$ & $\begin{array}{r}-(100) \\
+(\ldots) \\
++(\ldots) \\
++(\ldots) \\
+++(\ldots)\end{array}$ & $\begin{array}{r}-(100) \\
-(100) \\
-(100) \\
++(\ldots) \\
+++(\ldots)\end{array}$ & $\begin{array}{r}-(50) \\
-(50) \\
\overline{-}(40) \\
++(\ldots) \\
+++(\ldots)\end{array}$ & $\begin{array}{r}-(14) \\
\bar{z}(14) \\
\overline{-}(6) \\
++(\ldots) \\
+++(\ldots)\end{array}$ & $\begin{array}{r}-(2) \\
\bar{z}(0) \\
\overline{\bar{t}}(1) \\
+\overline{+}+(\ldots)\end{array}$ & $\begin{array}{r}-\quad(0) \\
=\quad(0) \\
=(100) \\
+++(\ldots)\end{array}$ \\
\hline
\end{tabular}

$+++=$ Profuse growth; other symbols as for table $\mathbf{I}$.

or largely recovered after overnight incubation from the tubes in which growth was inhibited. For some strains this difference appeared to be related to rough and smooth colonial morphology-the former being the more sensitive-but 
of two strains from which we were able to derive stable rough and smooth variants from the same culture, only one exhibited the distinction in sensitivity.

The effect of varying erythromycin concentration and population density for one strain $(F r)$ on which its action was bacteristatic is shown in table II. For each decade rise in the size of the inoculum above $10^{6}$ organisms per $\mathrm{ml}$, the

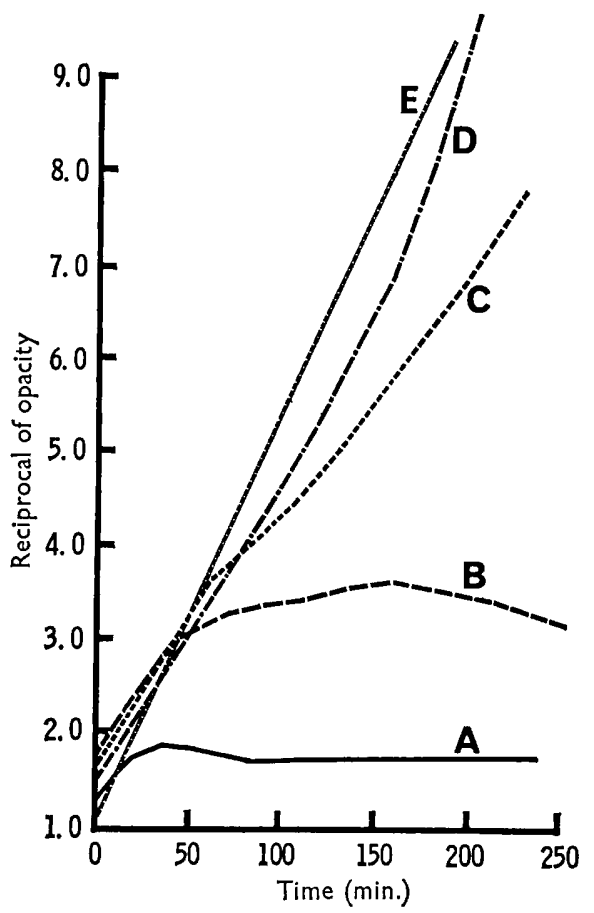

FIG. 1.-Reciprocal of opacity of $1: 3$ dilution of overnight broth culture of $E$. coli (strain $N o$ ) on dilution with fresh broth at $1 \mathrm{ml}$ per min. (A); plus initial addition of erythromycin: $50 \mu \mathrm{g}$ per ml (B); $100 \mu \mathrm{g}$ per ml (C);500 $\mu \mathrm{g}$ per $\mathrm{ml}(\mathrm{D})$. The effect of dilution on a formalinkilled culture is shown by curve $\mathrm{E}$.

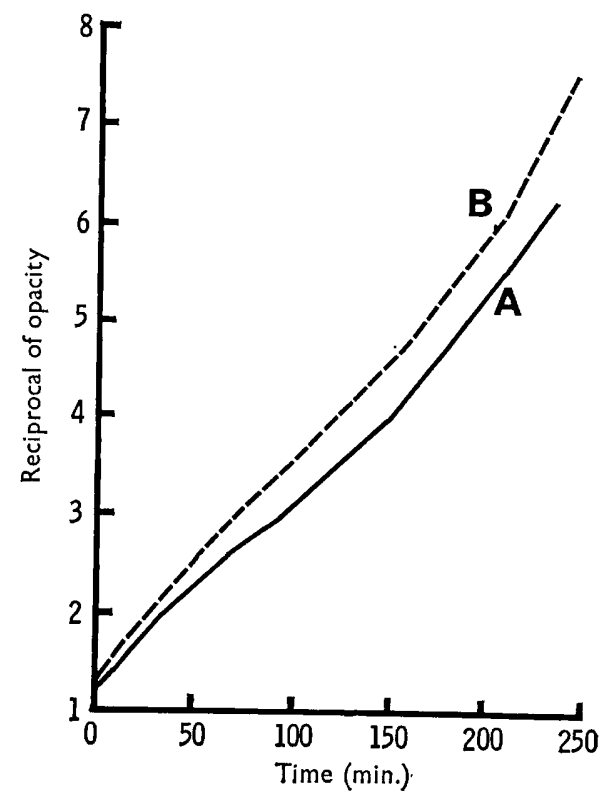

FIG. 2.-Reciprocal of opacity of $1: 3$ dilution of overnight broth culture of $E$. coli (strain $N o$ ) after initial addition of erythromycin and dilution at $1 \mathrm{ml}$ per min. with broth containing erythromycin to produce a constant concentration of $50 \mu \mathrm{g}$ per $\mathrm{ml}(\mathrm{A}) ; 100 \mu \mathrm{g}$ per $\mathrm{ml}(\mathrm{B})$.

MIC approximately doubled. From each tube in which inhibition was achieved, the original inoculum could be quantitatively recovered irrespective of antibiotic concentration or inoculum size.

One strain $(\mathrm{Fr})$ showing the purely bacteristatic effect, and one $(\mathrm{No})$ showing the apparent bactericidal effect in the tube titrations, were examined in the dilution system. The responses of the two strains to various concentrations of erythromycin are shown in figs. 1 and 3. An initial addition of antibiotic was made, and then both it and the culture were constantly diluted by the addition of fresh broth.

With strain No (fig. 1) an initial addition of erythromycin producing a concentration of $500 \mu \mathrm{g}$ per ml, equivalent to 15 times the MIC (15 MIC), caused total eclipse of the population (curve D) and even $3 \mathrm{MIC}$ (curve C) had a marked 
effect. At a concentration of 2 MIC (curve B), inhibition was reversible, the culture starting to grow as the antibiotic was diluted. This effect could be abolished by keeping the concentration constant by adding it with the diluent (fig. 2).

With strain Fr (fig. 3), an initial addition of sufficient erythromycin to produce a concentration of $500 \mu \mathrm{g}$ per ml (equivalent to $10 \mathrm{MIC}$ for this strain) had relatively little effect (curve D) compared with that exerted on strain No. On the other hand this effect, and even the minimal effect exerted by the MIC itself (curve B), was maintained despite continuous dilution of the culture.

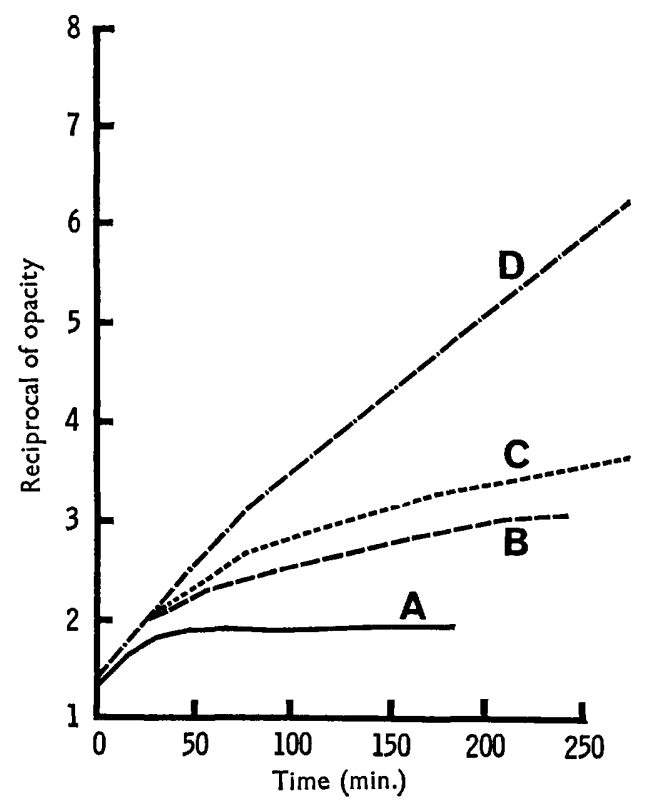

FIG. 3.-Reciprocal of opacity of 1:3 dilution of overnight broth culture of $E$. coli (strain Fr) on dilution with fresh broth at $1 \mathrm{ml}$ per min. (A); plus initial addition of erythromycin $50 \mu \mathrm{g}$ per ml (B); $100 \mu \mathrm{g}$ per $\mathrm{ml}(\mathrm{C}) ; 500 \mu \mathrm{g}$ per ml (D).

Corresponding differences in susceptibility between the two strains were found when erythromycin was tested for its ability to inhibit the lytic action of ampicillin, which proceeds very rapidly under these conditions (Greenwood and O'Grady, 1969, 1970). The degree of lysis of strains No and Fr by ampicillin added after $30 \mathrm{~min}$. is shown in fig. 4, curve A and fig. 5, curve A respectively. After a short lag during which the culture was being diluted, growth began; when ampicillin was added after 30 min., there was rapid lysis shown by the steep rise in the reciprocal of the opacity. Ampicillin lysis of strain No was completely inhibited by 3 MIC erythromycin (fig. 4 , curve C), the reciprocal of the opacity being very similar to that produced by erythromycin alone (fig. 1, curve C).

With the addition of 2 MIC erythromycin-which in the absence of ampicillin allowed growth to occur as continuing dilution reduced the concentration 
of the macrolide below the MIC (fig. 1, curve B)-the inhibitory effect of erythromycin disappeared as its concentration fell and ampicillin lysis developed (fig. 4, curve B). In contrast, ampicillin lysis of strain $\mathrm{Fr}$ was minimally inhibited by 10 MIC erythromycin (fig. 5, curve C) and not at all by 2 MIC even when this concentration of erythromycin was maintained (fig. 5, curve B).

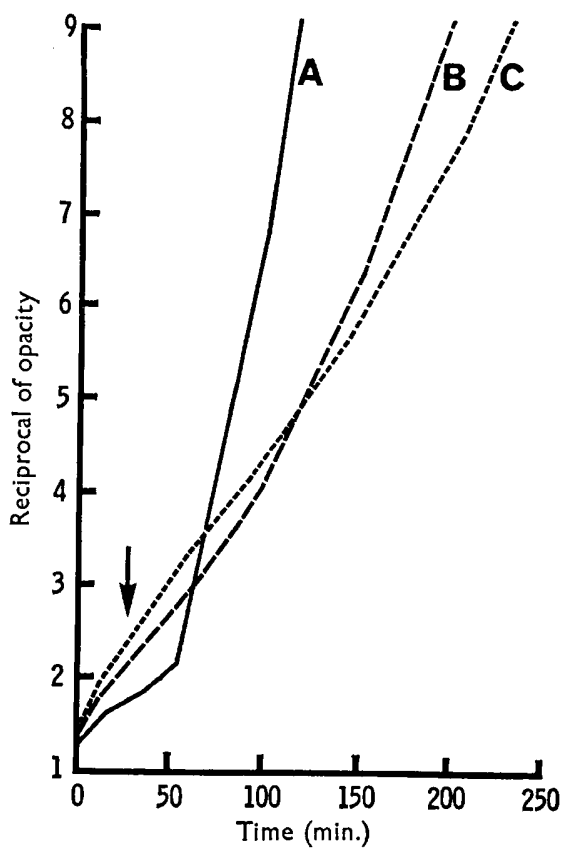

FIG. 4.-Reciprocal of opacity of $1: 3$ dilution of overnight broth culture of $E$. coli (strain $\mathrm{No}$ ) on dilution with fresh broth at $1 \mathrm{ml}$ per min. (A); plus initial addition of erythromycin $50 \mu \mathrm{g}$ per $\mathrm{ml}(\mathrm{B}) ; 100 \mu \mathrm{g}$ per $\mathrm{ml}$ (C). Ampicillin added to a concentration of $66 \mu \mathrm{g}$ per $\mathrm{ml}$ after $30 \mathrm{~min}$. (arrow) in each case.

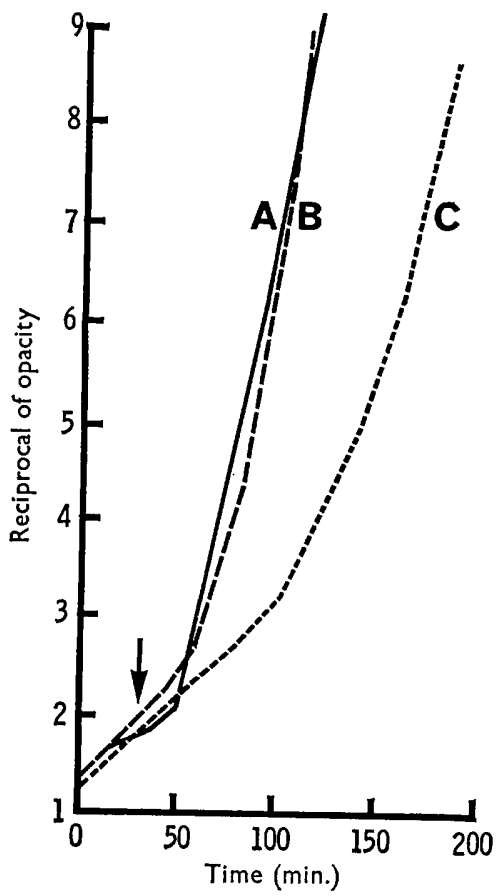

FIG. 5.-Reciprocal of opacity of $1: 3$ dilution of overnight broth culture of $E$. coli (strain $F r$ ) on dilution at $1 \mathrm{ml}$ per min. with: broth (A); broth containing $100 \mu \mathrm{g}$ erythromycin per $\mathrm{ml}(\mathrm{B})$; broth plus single addition of erythromycin to produce an initial concentration of $500 \mu \mathrm{g}$ per $\mathrm{ml}$ (C). Ampicillin added to a concentration of $66 \mu \mathrm{g}$ per $\mathrm{ml}$ after $30 \mathrm{~min}$. (arrow) in each case.

\section{DisCUSSION}

One of the most interesting and surprising results of this study was the finding of two distinct types of response of $E$. coli to the presence of erythromycin; 11 of the 16 strains studied showed a purely bacteristatic response but substantial killing occurred with the other five strains.

In conditions resembling those in the urinary bladder-high concentrations of bacteria subjected to constant dilution with fresh medium-two strains selected as typifying the bacteristatic and bactericidal types of response to erythromycin showed marked dissimilarities. The more sensitive No strain was totally inhibited by $15 \mathrm{MIC}$, and even $3 \mathrm{MIC}$ had a more profound effect than 
10 MIC had on the Fr strain. However, the action of bacteristatic concentrations of erythromycin on growth and on ampicillin lysis of the more sensitive No strain was found to be readily reversible while that on the less sensitive $F r$ strain was not. This is compatible with the view that the difference in the susceptibility of the two strains may lie in their permeability characteristics. Evidently the impermeability that hinders ingress of the antibiotic also prevents it from escaping.

These findings again emphasise that the effect of antibacterial agents in conditions that simulate even to a limited extent those likely to occur in vivo may be different from those in conventional in-vitro tests of antibiotic sensitivity. Studies along these lines of strains of enterobacteria isolated from infected urine might make it possible to predict with greater accuracy the outcome of treatment.

\section{SUMMARY}

Strains of Escherichia coli showed two types of response to erythromycin in conventional doubling-dilution titrations. For 11 of 16 strains, the original inoculum could be wholly or largely recovered from tubes in which there was no growth after overnight incubation. For the remaining five strains, no survivors could be recovered from tubes in which growth was inhibited. Two strains selected as typifying the bacteristatic and bactericidal responses behaved differently when exposed to erythromycin and continuously diluted with fresh medium as in the urinary bladder. Growth, and also lysis by ampicillin, of a strain showing the bactericidal response were inhibited by lower concentrations of erythromycin than those required to produce comparable effects in a strain showing the bacteristatic effect. On the other hand, the inhibitory effects on growth and ampicillin lysis disappeared as continuing dilution reduced the concentration of erythromycin below the MIC for a strain showing the bactericidal effect but not for the strain showing the bacteristatic effect.

We are indebted to Messrs Eli Lilly for a grant towards the cost of this work.

\section{REFERENCES}

Greenwood, D., AND O'Grady, F. 1969. A comparison of the effects of ampicillin on Escherichia coli and Proteus mirabilis. J. Med. Microbiol., 2, 435.

Greenwood, D., AND O'Grady, F. 1970. Trimodal response of Escherichia coli and Proteus mirabilis to penicillins. Nature, Lond., 228, 457.

O'Grady, F., AND Pennington, J. H. 1966. Bacterial growth in an in vitro system simulating conditions in the urinary bladder. Br.J. Exp. Path., 47, 152.

O'Grady, F., ANd Pennington, J. H. 1967. Synchronized micturition and antibiotic administration in treatment of urinary infection in an in vitro model. Br. Med.J., 1, 403.

ZinNer, S. H., SABath, L. D., CASEY, JoAN I., AND Finland, M. 1971. Erythromycin and alkalinisation of the urine in the treatment of urinary-tract infections due to Gramnegative bacilli. Lancet, 1, 1267. 